\title{
Seasted Floating City. Innovative Development of a New City Model
}

Lina K. Suárez ${ }^{1}$

\begin{abstract}
Seastead is a floating city experiment for international waters based on economic studies carried out by the Seasteading Institute, which seeks to increase real estate market growth, driven by an economic incentive dedicated to medical tourism, aquaculture, technology incubators, and support platforms for offshore rigs. A new pre-conceptual model of a floating city was created, conceptualizing an analysis of the floating habitat as a means for development and expansion. This new habitat style was designed taking into account considerations of the marine habitat, current habitats, utopian projects and studies regarding the expansion of urban spaces. The city was designed on a semi-submersible offshore platform chosen through a parametric model made by the Seasteading Institute, which allowed for a final modular array comprised by 300 containers organized by a crane system, this being the organizational system of the city.
\end{abstract}

Key words: Floating city, future cities, floating habitat, innovation.

\section{Resumen}

Seasted presenta el experimento de una ciudad flotante en aguas internacionales con base en estudios realizados por el instituto Seasteading, el cual busca incrementar el crecimiento de mercado en bienes raíces, conducido por un incentivo económico dedicado al turismo médico, acuicultura, incubadoras de tecnología y apoyo para las plataformas de perforación costa afuera. Un nuevo modelo pre-conceptual de ciudad flotante fue creado, conceptualizando un análisis de hábitat flotante como medio de desarrollo y expansión. Este nuevo estilo de entorno habitacional fue diseñado teniendo en cuenta consideraciones del ambiente marino, hábitat actual, estudios utópicos y estudios referentes a expansión de espacios urbanos. La ciudad fue diseñada en una plataforma semi-sumergible costa afuera elegida a través de un modelo paramétrico realizado por el instituto Seasteding, el cual permitió una formación modular final compuesta por 300 contenedores organizado por un sistema de grúas, siendo este el sistema organizacional de la ciudad.

Palabras claves: Ciudad flotante, ciudades del futuro, hábitat, innovación.

Date Received: March 29 2016 - Fecha de recepción: Marzo 29 de 2016

Date Accepted: June 17th 2016 - Fecha de aceptación: Junio 17 de 2016

${ }^{1}$ Architect. Ms.C Naval Architecture. Email: linast00@gmail.com 


\section{Introduction}

This document seeks to inform about the methodology used in the process of developing a floating city that could resemble the sustainable city model and suitable for various uses on international waters.

This work was developed based on a report of the DPEA of Naval Architecture of Nantes, which focused on the analysis of the state of the art in floating habitats worldwide, analyzing options for lasting and thriving economic growth, on the basis of on-water architecture, mainly considering worldwide social concerns and innovation opportunities in an innovative manner. Initially, activities performed since the Middle Ages up to present day were identified, showing that water is useful for power generation, transport, and tourism among others, reason for undertaking the development of a vanguard floating habitat model. Meanwhile, in California, Seasteading was in charge of producing a concept for permanent housing at sea, which is not ruled by any country, created on the basis of an economic model seeking to facilitate establishing autonomous floating communities on marine platforms operating in international waters.

The merger of these two studies enabled the materialization of the modular floating Seastead city, which started being developed on an offshore platform that had to be strategically located close to Silicon Valley, $200 \mathrm{NM}$ off the east coast of the United States.

Development started by taking into account the various types of missions that may be undertaken by the same model, which should allow multipurpose functions of the platform, such as a technology incubator (software development), medical tourism (experimental medical treatments), aquaculture or fish farming, OTEC (Ocean Thermal Energy Conversion), resort, offshore casino, among other similar purposes.

A design methodology was developed which enabled the conceptual development of an autonomous modular floating city that allows innovation of new social policies and systems. This is part of a Seasteading research project that is currently seeking development under the "The Foating City Project", which can be found on the following website: http://floating-city.org.

\section{Background}

The floating habitat has created a signature lifestyle in the communities and times where it has been built, providing commercial, urban, artisan, utopian and even fantastic developments such as Jules Verne described in L'Ile a hélice " qui sait si la terre ne sera pas trop petite un jour pour ses habitants dont le nombre doit atteindre six millards en 2072 ...et ne faudra t-il pas bâtir sur la mer, alors que les continents seront encombres? ».

Various habitats have been created throughout the years, some out of necessity, adaptation to the environment, luxury, exclusiveness, urbanistic studies, creation of new communities, or simply for the creation of micro-nations in the world.

Since 1359, in Lake Inle in Burma, Asia, wooden and bamboo houses were built on piles that are still standing, due to their geographical location, crops and houses are placed above water. Thai and Vietnamese cultures also have great development in lacustrine villages, one of them in the Andaman Sea, which holds maritime nomadic people known as "Moken ", or sea gypsies, who preserve their sea-based ancestral culture; Zhouzhuang, created in 770 B.C. It preserves ancient houses and bridges, and it is thus recognized as the \#1 water community in China, holding a UNESCO World Heritage designation ${ }^{1}$.

In Europe, between the Neolithic and the Bronze Ages (4300 to 800 A.C.), the Swiss lacustrine villages were populated by the littoral prehistoric groups. Currently, due to expansion, Holland has urban development projects, residential and commercial constructions above water. During the Middle Ages, bridges were used as commercial galleries and residences, such as the still preserved

\footnotetext{
http://whc.unesco.org/en/tentativelists/5328/
} 
Pont Vecchio in Florence, built between 1335 and 1345, or the old London Bridge, built in 1745, or the Hotel Dieu bridge, massively built in 1499; cities such as Venice, which was built on the lagoon sand and supported on thousands of wooden piles; and micro nations such as today's Sealand appeared, which established on a military platform in 1967 , and currently lodges only 5 people and is proclaimed as an independent territory ${ }^{2}$.

In Africa, the Ganvie village located in Lake Nokoue, Benin, was established between XVI and VXII, and holds one of the largest African populations living in a lake It is recognized by the water-based activities performed by its people, and is currently a tourism hotspot.

There is a Latin American indigenous group, the Uros, a pre-Inca people that live on 42 selffashioned floating islands in Lake Titicaca; this group weaves their temporary islands for their homes with totora, which demands a new layer every two weeks to prevent the islands from sinking ${ }^{3}$; in 1325 , Tenochtitlan was built on an island in lake Texcoco, as capital of the Mexican empire.

Based on the ideal world of the $60 \mathrm{~s}$ and $70 \mathrm{~s}$, countless utopian floating cities were created, such as Kisho Kurokawa's Helix for Kasumigaura, Japan, in 1961, which is developed into mega spirals based on the $\mathrm{DNA}^{4}$ structure; the Urban Matrix or Flattions Resort Complex by Stanley Tigerman in 1967 and 1972, respectively, sought to extend a metropolis on an aluminum lightweight structure shaped as a tetrahedron to generate less resistance to the marine elements. Projects linked to the Tokyo bay development by Paul Maymont in 1959 and Kenzo Tange in 1961 were aimed at generating spaces for me city's overpopulation; the Lingang New City, developed by GMP in Shanghai sought an economic, commercial, and financial megapolis to support the Shanghai business hub; the modular Floating City created by Craven and Kikutake in 1970 was developed to reduce congestion in Honolulu. Even an amphibious city was conceived

$2 \mathrm{http} / / / \mathrm{www}$. sealandgov.org

$3 \mathrm{http} / / /$ punoperu.orige nandino.com/isla-de-los-uros.html

${ }^{4}$ http://www.kisho.co.jp/page.php/200 by Lacroix-Verdeaux in 1971, dedicated to maritime relaxation as an amphibious vacation site.

Considering the various issues identified and the favorable arguments to address the development of a multifunctional floating structure, the search for the development of aquatic projects that will allow improvement for the current living conditions, and as a consequence, the development of an individual and collective habitat defined on the basis of a physical and moral condition that addresses the psychological and physiological needs of the 21st century mankind.

\section{Development process}

"The Laws on the water are different from those on land" 5

We made first contact with Seasteading, which has been on a 5-year search of a solution to social issues, from the baseline of a permanent research process for the innovative development of offshore floating communities, which has explored waste disposal all the way through coexistence halls.

Seasteading decided to develop floating cities in international waters taking advantage of the "freedom of the high seas", which is established in the United Nations Convention on the Law of the Sea under Article 87, with the purpose of using the ultimate non-claimed territory on earth, which therefore is not subject to any regulation, allowing personal freedom, experimenting on a new social, political and economic system.

\section{Development}

The following procedure was used to develop the platform:

- Identification of requirements

- Study of design constraints

- Typological volume definition

- Internal functional analysis

\footnotetext{
5 K. Olthuis y D. Keuning. Float! Building on water to combat urban congestion. Pag, 239. 2011.

${ }_{6}^{6}$ http://floating-city.org/
} 
- Reconfiguration

- Design of dwelling types

\section{Identification of requirements}

Development of a sustainable, legal, and technological aquatic civilization was proposed on a $300 \times 300$ ' offshore platform, comprised by a pontoon, four columns and a semisubmersible ring selected by Seasteading after a parametric analysis created to configure floating platforms and designed under the main requirements defined by the Institute.

Table 1. Main requirements.

\begin{tabular}{|c|c|}
\hline \multicolumn{2}{|c|}{ Functional requirements } \\
\hline \multirow{5}{*}{ Accommodation } & 400 people in $300 \mathrm{ft}^{2}$, approx. \\
\hline & $\begin{array}{l}75 \% \text { people in } 600 \mathrm{ft}^{2} \text { units for } \\
2 \text { persons }\end{array}$ \\
\hline & $\begin{array}{l}25 \% \text { people in } 900 \text { to } 1200 \mathrm{ft}^{2} \\
\text { for } 3 \text { or } 4 \text { persons }\end{array}$ \\
\hline & $\begin{array}{l}40 \text { guests in } 120 \text { to } 180 \mathrm{ft}^{2} \\
\text { spaces per person }\end{array}$ \\
\hline & $\begin{array}{l}10 \text { luggage in single private } \\
\text { spaces }\end{array}$ \\
\hline Public areas & $\begin{array}{l}2 \text { levels combining an inner } \\
\text { area of less than } 100,000 \mathrm{ft}^{2}\end{array}$ \\
\hline Service areas & Front desk \\
\hline \multirow{3}{*}{ Commercial spaces } & Stores \\
\hline & Supermarket \\
\hline & Coffee shops and restaurants \\
\hline \multicolumn{2}{|c|}{ Structural requirement } \\
\hline \multirow[b]{2}{*}{ Static load } & $>94 \mathrm{lb} . / \mathrm{ft}^{2}$ inner spaces \\
\hline & $\begin{array}{l}\text { Consider ice, snow, or water } \\
\text { accumulation on decks }\end{array}$ \\
\hline \multicolumn{2}{|c|}{ Habilitation/enabling and safety requirements } \\
\hline & $\begin{array}{l}\text { Sikorsky-61 helicopter } \\
\text { accommodation }\end{array}$ \\
\hline & $\begin{array}{l}\text { Fire code compliance, fire } \\
\text { alarms }\end{array}$ \\
\hline & Command and control bridge \\
\hline & $\begin{array}{l}\text { Vessel docking platform and } \\
\text { recreational space }\end{array}$ \\
\hline
\end{tabular}

\section{Design constraints}

Once the platform requirements and dimensions were known, the offshore implantation site was analyzed, using information provided by a NOAA (National Oceanic and Atmospheric Administration) buoy named station 46059 located at $357 \mathrm{NM}$ west of San Francisco, coordinates $38^{\circ} 2^{\prime} 49^{\prime \prime} \mathrm{N} 129^{\circ} 58^{\prime} 8^{\prime \prime} \mathrm{W}$. The data shown in Table 2 corresponds to these coordinates, which was considered in the design of the platform superstructure.

Table 2. Main requirements.

\begin{tabular}{|c|c|c|c|}
\hline \multirow{2}{*}{ Wind speed } & $\operatorname{Max}$ & 45 & $\mathrm{kn}$ \\
\hline & Average & 7 to 22 & $\mathrm{kn}$ \\
\hline \multirow{3}{*}{ Air Temperature } & $\operatorname{Max}$ & 22 & ${ }^{\circ} \mathrm{C}$ \\
\hline & Min & 5 & ${ }^{\circ} \mathrm{C}$ \\
\hline & Average & 10 to 19 & ${ }^{\circ} \mathrm{C}$ \\
\hline \multirow{3}{*}{ Sea Temperature } & Max & 21 & ${ }^{\circ} \mathrm{C}$ \\
\hline & Min & 10 & ${ }^{\circ} \mathrm{C}$ \\
\hline & Average & 11.5 to 19.5 & ${ }^{\circ} \mathrm{C}$ \\
\hline \multirow{2}{*}{ Wave height } & Max & 14 & $\mathrm{~m}$ \\
\hline & Average & 2.5 to 5.5 & $\mathrm{~m}$ \\
\hline \multirow{2}{*}{ Wave period } & Max & 15.5 & $s$ \\
\hline & Average & 5.5 to 9.5 & $s$ \\
\hline
\end{tabular}

Considering that the parameters of the semisubmersible offshore platform provided for the development of this city had been studied and thus selected, developing the superstructure was the most important process.

\section{Typological definition}

Upon identification of the location conditions, requirements, worldwide references in floating city design, usage of green technologies, among others, a process of functional and aesthetic volumetric location began, to meet the ideal neighborhood or city that the people of Seastead would pursuit.

Taking into account that the only means of transportation to reach it are by sea or air, that the recreation sites should be related to the sea and air, that housing should be modular and ephemeral, that workspaces should be suited to the characteristics of the desired business and that social issues depend on the new open social system a typological definition to 
achieve the purpose of the city, which allows for economical growth, increase in quality of life, higher social and cultural justifications and new entrepreneurial models had to be developed.

Models were developed for the Seasteading mini-city aimed at defining space requirements for human development, considering their physical well-being and their social needs, stressing on the mixed uses in one same platform, given its small dimensions.
Each model considered a suitable allocation of areas and sub-areas to foster normal life cycles, holding homes (private), a work or education space (demiprivate), and a socialization space (public). Each one of these spaces meets international standards for a person's habitation and development.

As the volumetric analysis of each one of these proposals was completed, prioritization elements of the models were identified, such as weight analysis, sustainable system alternatives, stability analysis and dwelling area design.

Fig. 1. Typological definition options.
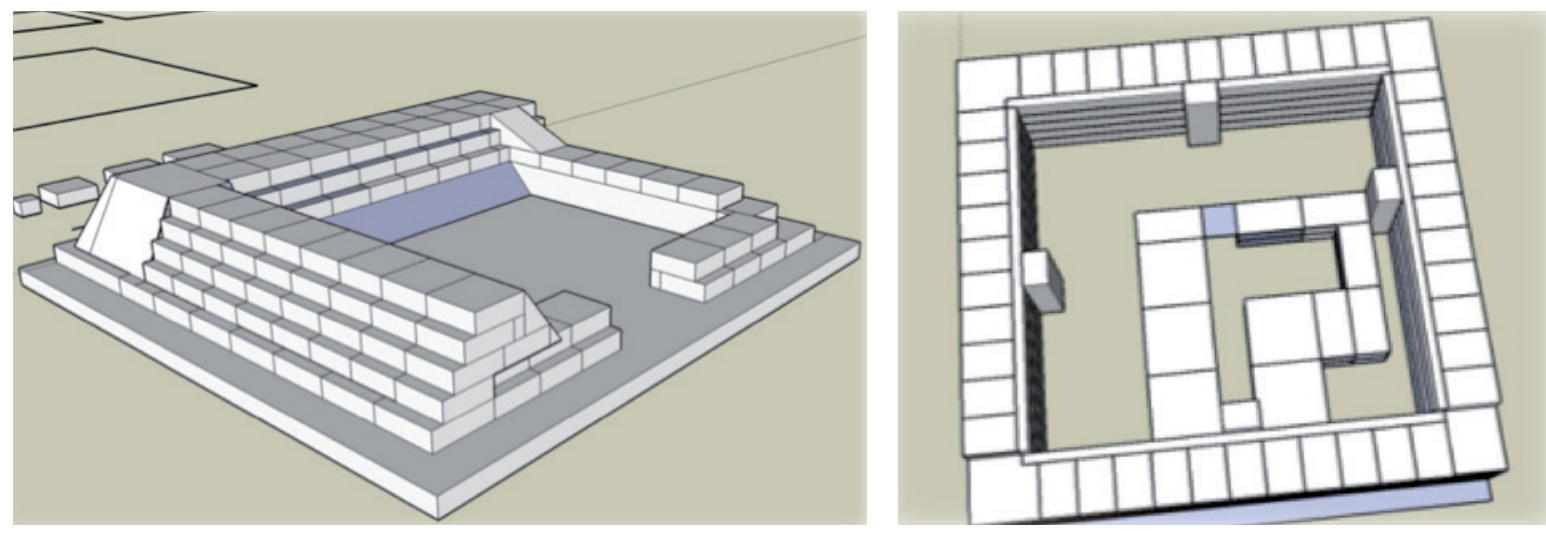

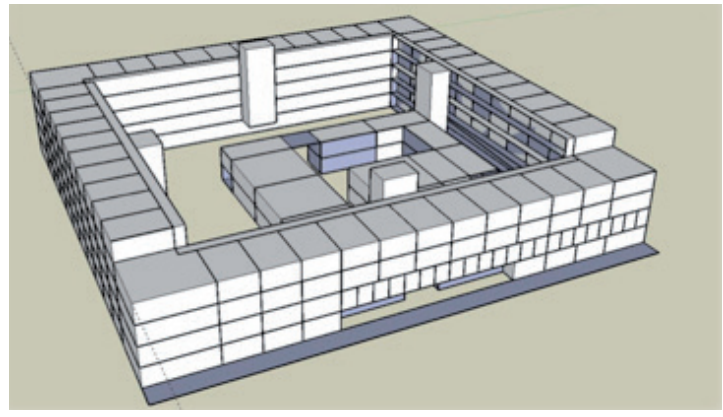

Internal functional analysis

A typological model was selected to be analyzed from the functional standpoint to meet each function of a sustainable city. Locating residential areas, work areas, commercial areas, circulation, hotel area, technical area, and central recreational spaces in terraces, the middle area of the platform with a direct connection to the ocean.

Fig. 2 shows one of the latest functional analysis performed to define the final model, displaying its external structure in Fig. 3.

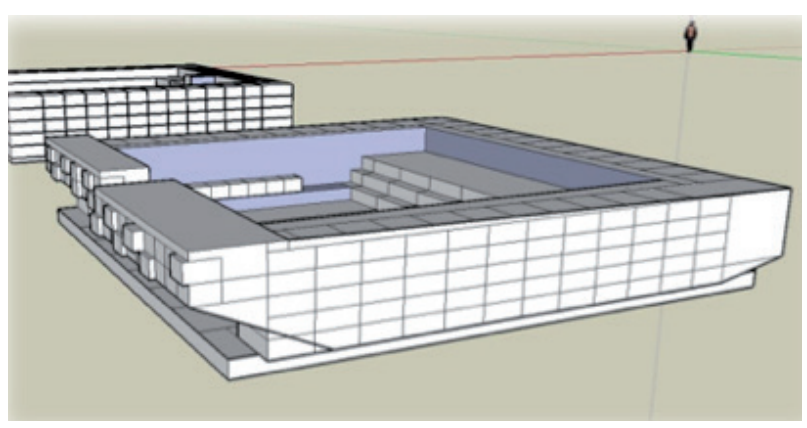

Reconfiguration

After a few months of analysis, the Seasteading Institute, requested a new superstructure model only using containers in order to reduce the cost of the platform and to enable its consolidation process.

A similar design process was undertaken, using the same location, performance specifications and design restrictions previously identified. After a long analysis the main hubs of the platform were determined to be cranes that would allow arranging the containers in the Seastead city, and 
therefore several arrays such as the ones shown in Fig. 4 were prepared.

\section{Dwelling type design}

Considering the crane as the main hub for the volumetric organization, it was conceived as the connection point for each container, suggesting a connection of the utilities supplied by the platform for these ephemeral dwellings.
The idea is that people interested in trying out living in a floating city to develop new businesses, may connect and disconnect, generating movement and an extended use of the dwelling modules.

With this purpose, 60 fixed containers and 240 mobile containers were crafted, all with the option for any of the configurations proposed in Figs. 5, 6 , and 7 .

Fig. 2. Internal Functional Analysis.

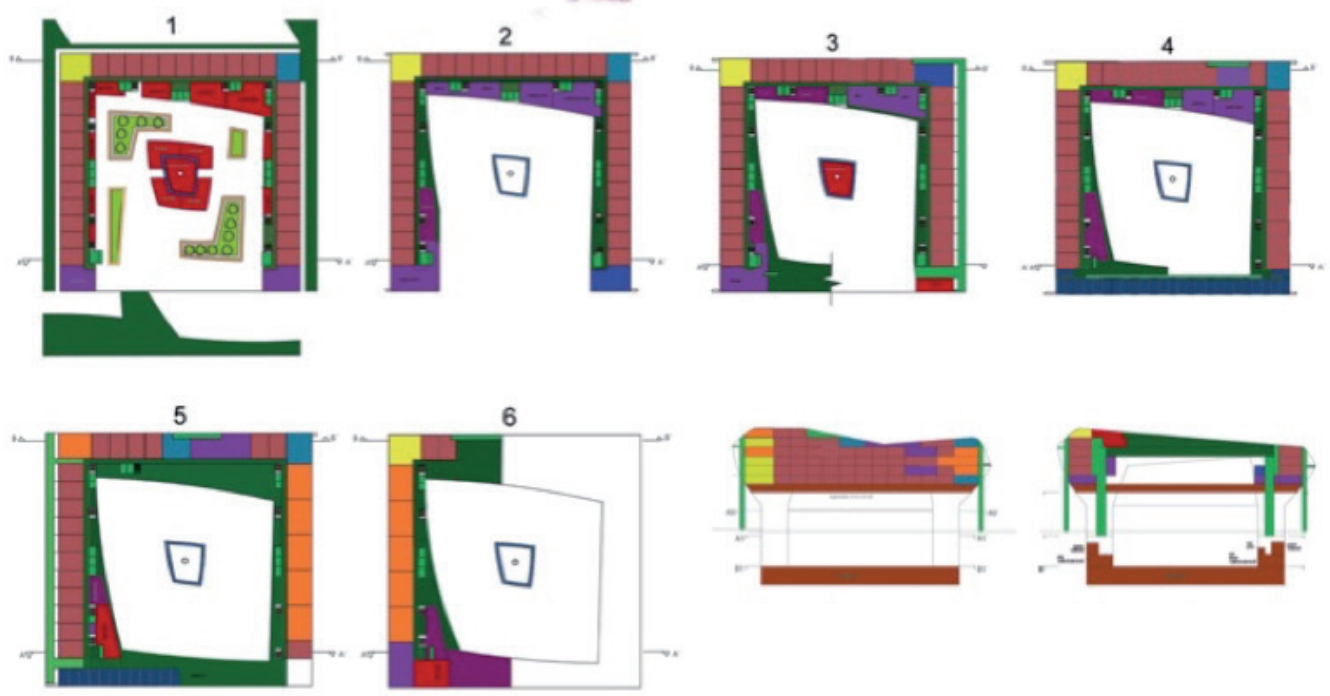

Fig. 3. External Artistic View.

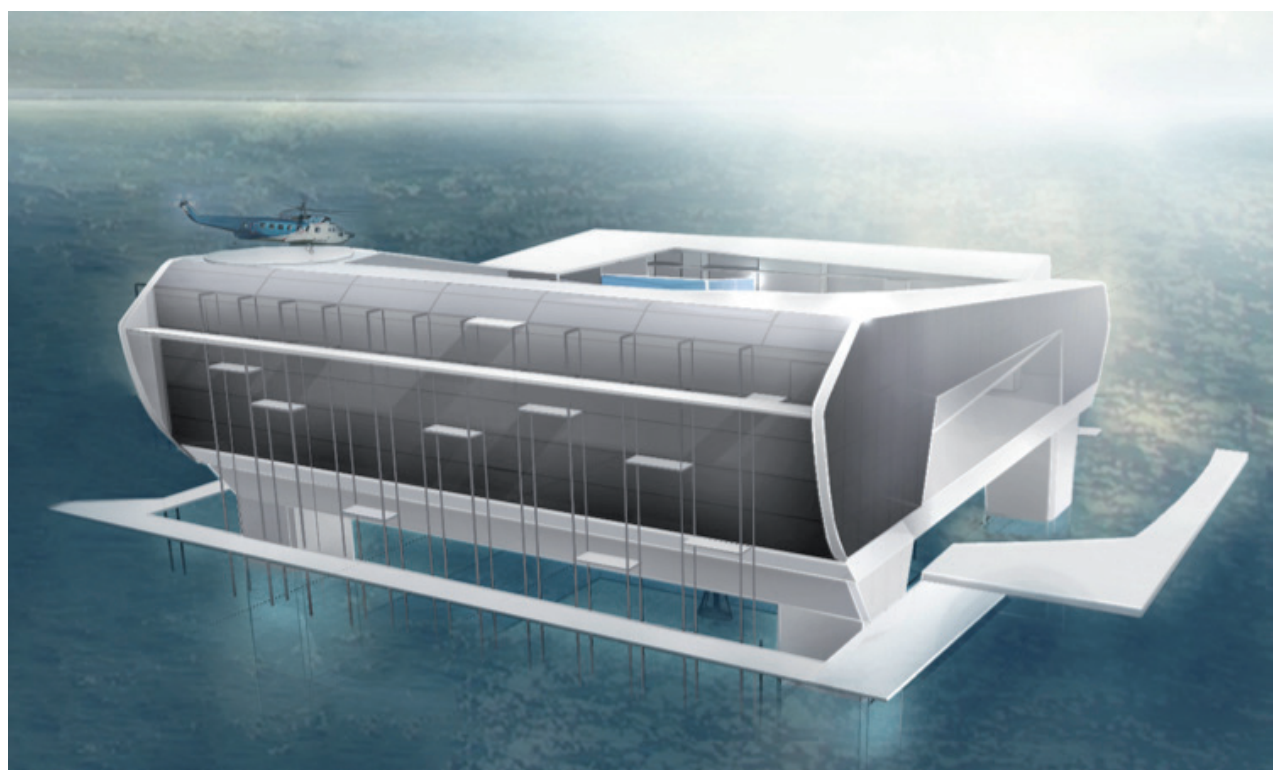


Fig. 4. Container type array.
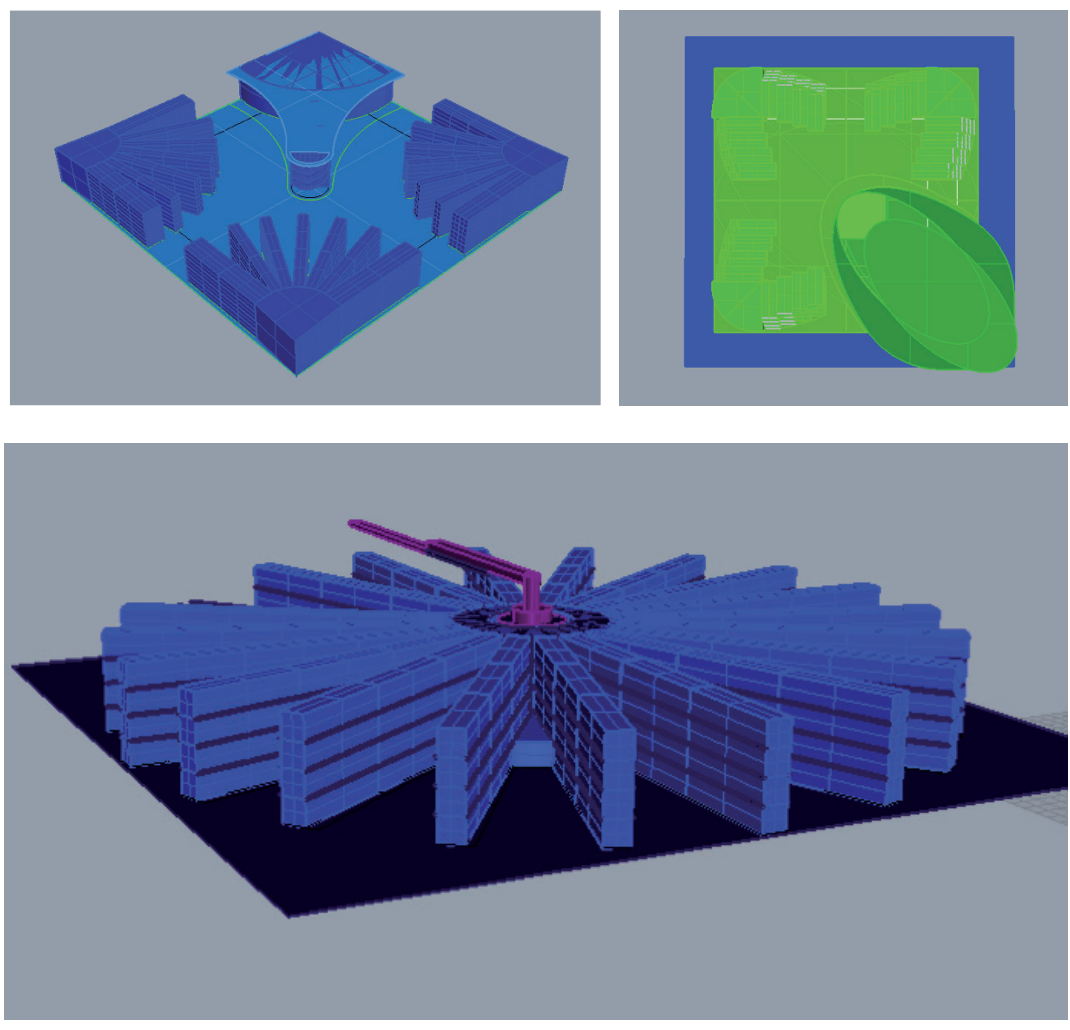

Fig. 5. Type 1 simple model.

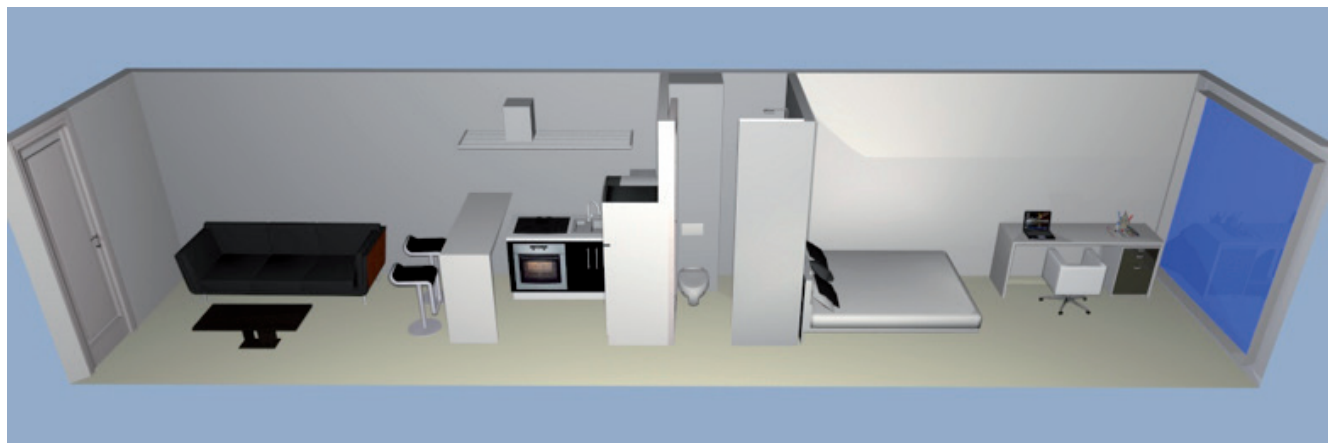

Fig. 6. Type 2 simple model.

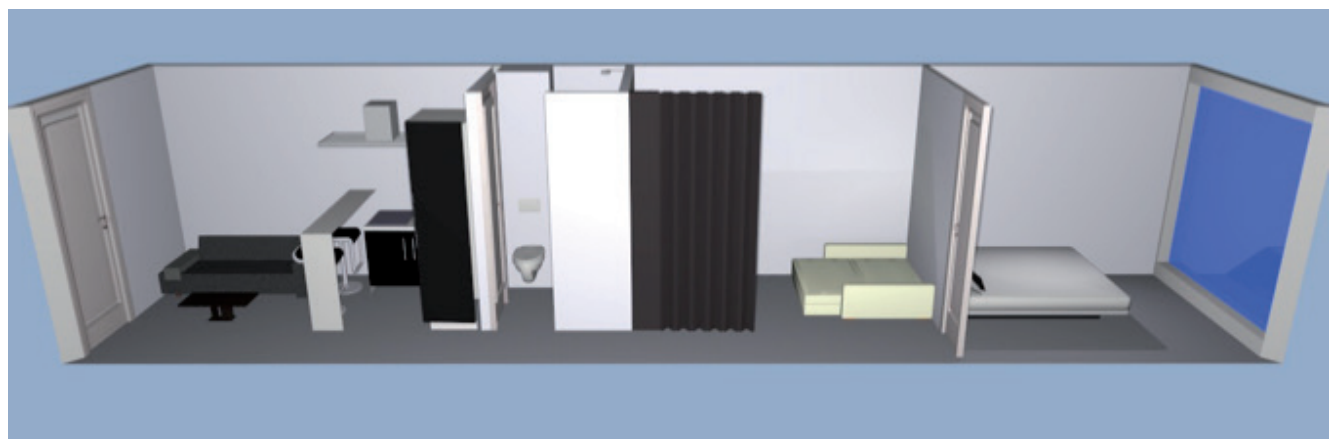


Fig. 7. Type 3 dual model.

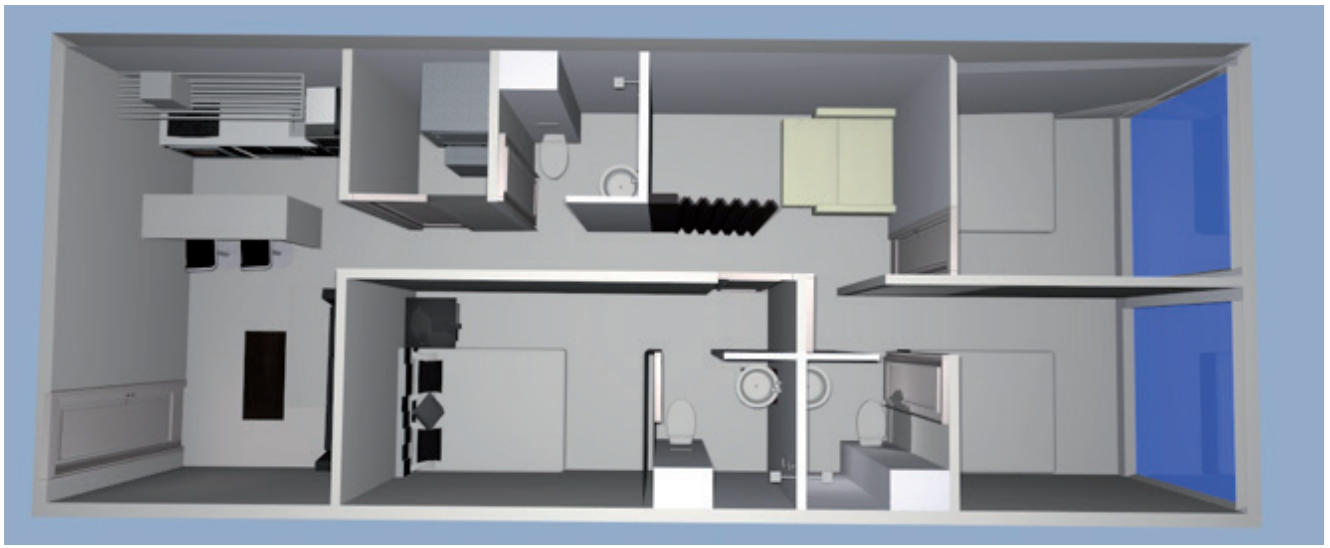

Fig. 7. Type 3 dual model.

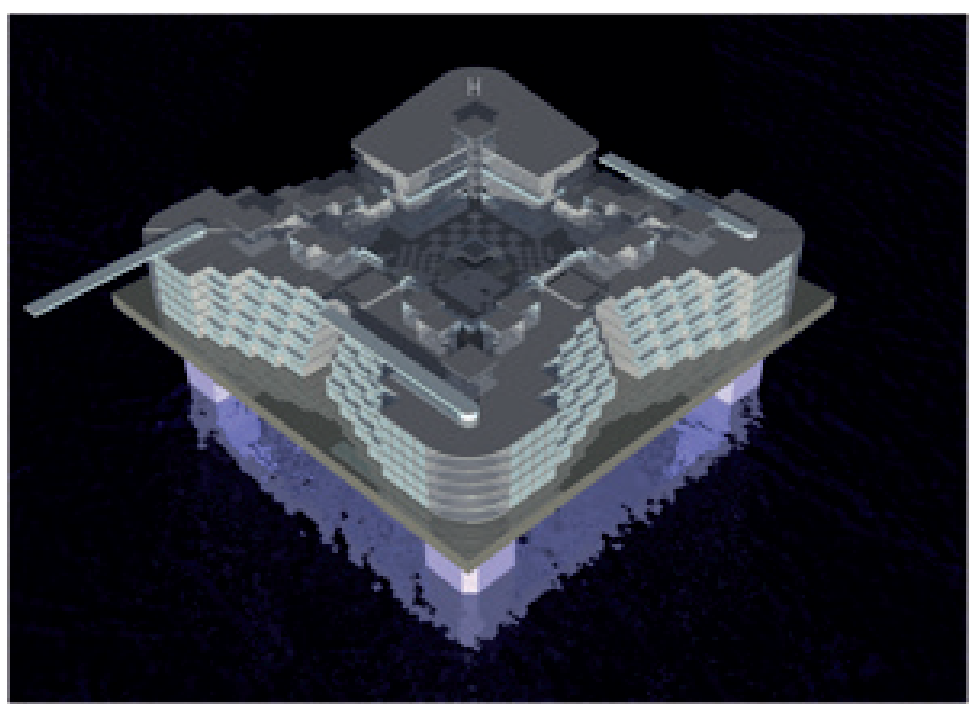

The superstructure for a platform was designed with the following characteristics:

\begin{tabular}{ll}
\hline LWL & $\frac{77.4 \text { meters }(245 \mathrm{ft})}{20.6 \text { meters }(67.8 \mathrm{ft})}$ \\
\hline BwL & $\frac{21.3 \text { meters }(70 \mathrm{ft})}{60.9 \text { meters }(200 \mathrm{ft})}$ \\
\hline Maximum draught & $\frac{26150 \text { Tons }}{300}$ \\
\hline $\begin{array}{l}\text { Displacement } \\
\text { of containers }\end{array}$ &
\end{tabular}

We found that the development of cities such as Seastead has many functional demands due to the need for psychological and physiological compliance in a sustainable and innovative space, arising from the need for innovation and product services, and/or procedure development for successful applications, where knowledge through creativity and vanguard prevails. Implementing new concepts, therefore, promotes process creation, production, and transformation.

\section{References}

BUREL FABRICE. Habiter la mer: histoire, et at des lieux et prospective. Nantes, Ecole nationale superieure d' architecture de Nantes, 2011. DPEA Navale. 

MARIA ERIC, MENETREY PHILIPPE.
Le monolithe. Presses polytechniques et universitaires romandes, 2012. ISBN10:2880745144

UNITED NATIONS, United Nations Convention on the Law of the Sea, 1958-60. Website: http://www.un.org/depts/los/convention_ agreements/texts/unclos/convemar_es.pdf

OLTHUIS K, KEUNING D. Float building on water to combat urban congestion, Frame 2011. ISBN: 9789077174296

PETRIE GEORGE. Parametric Analysis of candidate configurations for early seastead platforms, Part 1. USA 2011
RAGON MICHEL. Où Vivrons-nous demain, 2012. Paris Laffont. p 215. ASIN: B0014QG7UG

REVISTA RELATIONS N48, Les dalles flottantes

ROUGERIE Jacques y VIGNES Edith. Habiter la mer. Editions Maritimes \& d' autre mer. 1978. p,197. ASIN: B000XC7260

WILLEMIN Veronique. Maisons sur l' eau. Editions Alternatives, 2008. P,125. ISBN2862275468 